\title{
ELEMENTS OF PRECISION AGRICULTURE IN MALTING BARLEY CULTIVATION AND THE USE OF BARLEY STRAW FOR ENERGY PURPOSES
}

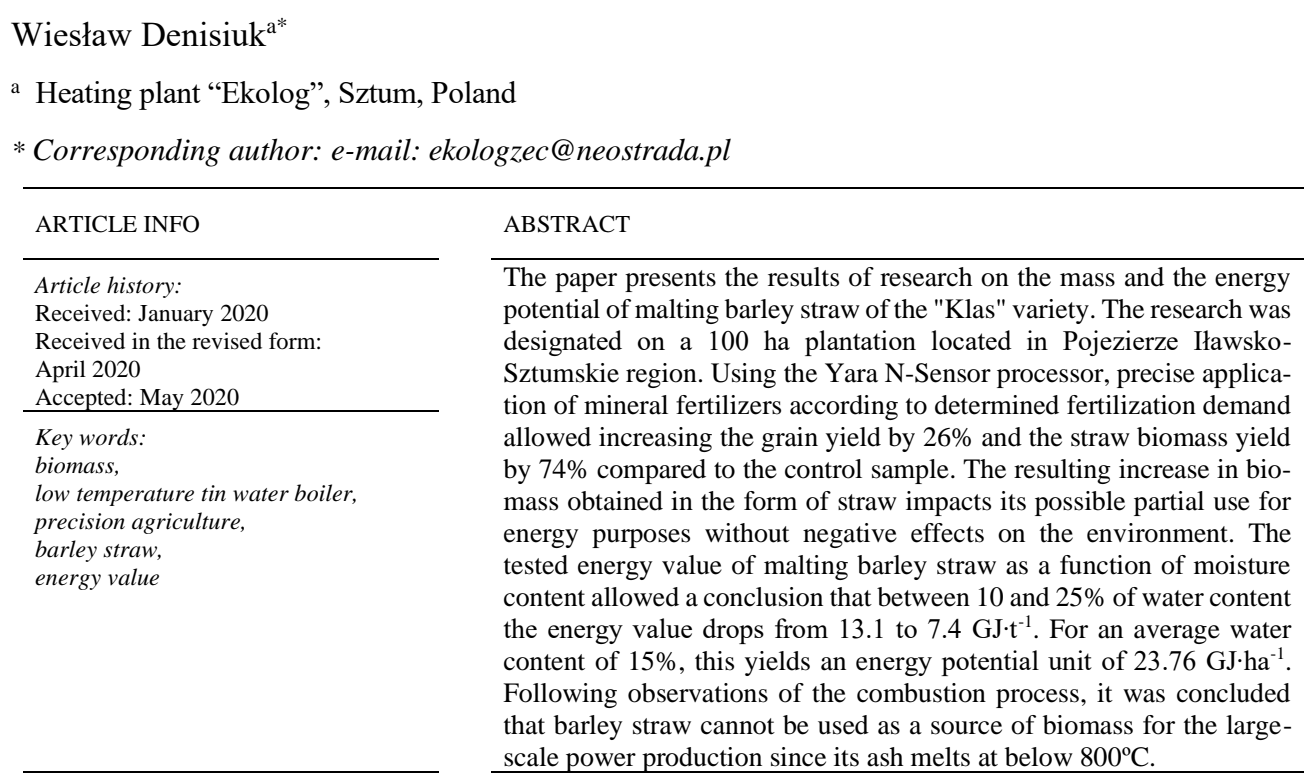

\section{Introduction}

Food, shelter, power and clean environment, are everyday basic human concerns. To address problems affecting the global community, many concepts and technologies have been created (Denisiuk, 2005). The concern for the natural environment and its protection against excessive use of ubiquitous synthetic plant protection products partly overcomes its effects, provided that chlorophyll meters: N-Tester and N-Sensor, are used in agricultural production. These devices are used to support management decisions with biotechnology (Denisiuk, 2016; Higa, 2003). Precise agricultural production and modern cultivation, which should be combined with the application of optimal amounts of chemical fertilizers for specific geographical and natural conditions, as well as plant needs, brings measurable benefits, e.g., an increased yield of the harvested grain and straw.

A part of environmental protection activities is local energy production, preferably dominated by renewable energy sources (RES) (Denisiuk, 2005; Grzybek, 2010; Guła, 2007). However, the European Commission made a questionable decision in terminating support for energy plantations in late 2009. In the "old" Member States, subsidies for biomass production 
enabled the development of local power production in villages and small towns. With regard to the obligation to include $20 \%$ of RES in their energy balance, imposed on the member states, Poland's position (Żmuda, 2011) indicates that:

- the need to direct subsidies for establishing energy plantations, if renewable energy development is to be a reality,

- the legitimacy of targeting support to areas with poor soil valuation, where food production is expensive and inefficient (energy plant production can't be in competition to food production).

- the subsidies should relate to obtaining energy biomass from:

1. permanent grassland if it is not usable for raising and breeding cattle, goats, horses and sheep,

2. biomass from plant by-products, including straw, leaves of root vegetables and other plants, which are not used to reproduce humus in soil,

3. liquid and solid manure,

4. biodegradable waste from the agri-food processing industry and the biodegradable part of solid and liquid municipal waste from cities, towns and villages.

In terms of physical and chemical characteristics, plant biomass is a heterogeneous raw material. The use of biomass for energy purposes requires its characterization mainly in terms of moisture content and volatile components, as well as determination of the calorific value and content of elements such as carbon, nitrogen, hydrogen, sulfur. These parameters depend on the physiological characteristics of various plant species and varieties, as well as the development phase of the plant from which the biomass was obtained, plant part, its habitat, as well as date and methods of harvesting, transport, storage and other factors (Graham et al., 2016; Krzyżaniak et al., 2014; Szyszlak-Bargłowicz et al., 2006).

Barley straw has a significant, yet unused mass and energy potential, especially in southern Poland, where other cereals have little potential. It can constitute a significant potential for small power production in farms located in this area (Denisiuk, 2009; Guła, 2007). Support for barley production with precision farming tools allows increasing not only the grain yield, but also that of straw, as an energy raw material. However, as stated by Nikolaisen (1998), Nilsson and Hansson (2001), this type of straw is not recommended for large-scale power production, associated with high-temperature and steam boilers. The reservation relates to the technical parameters of the melting temperature of ash produced from barley straw combustion. The produced molten ash, cooled down on the boiler walls in the flame tube and the heat exchanger area, can lead to its clogging and destruction.

\section{Purpose of the study}

The purpose of the paper was to determine the index parameters of the mass and the energy potential of malting barley grain and straw, using both a traditional and a modern production method, using precision agriculture tools. The purpose of the work was also to determine the energy value of barley straw combustion in a $500 \mathrm{KW}$ tin water boiler, depending on its humidity. 
Elements of precision agriculture...

\section{Materials and methods}

100 ha of malting barley of the 'Klas' variety was contracted in a farm in the Pojezierze Iławsko-Sztumskie region. According to the contract, the recommended plant growing and fertilizing technology was used. The plantation, along with cultivation, fertilization and protection treatments, was carried out with the use of Yara precision agriculture tools, i.e. $\mathrm{N}$-Tester and $\mathrm{N}$-Sensor. For the purposes of this study, two zero tramlines have been marked out, for which traditional cultivation, fertilization and protection methods were used, based on the principles of plant cultivation. The zero tramlines were separated by three tramlines on which the amount of nitrogen fertilizer sowing was controlled by a Yara N-Sensor processor; each tramline had an area of 3.6 ha.

During harvest, the mass of the harvested grain was measured using a RINSTRUM Europe GmbH R320 weighbridge, with an accuracy of 0.01 . The malting barley grain from the zero tramline and the precision farming area were weighed separately. A Claas Lexion combine harvester was used to harvest the malting barley grain. The mass of bales of compacted barley straw biomass was also measured, separately for the zero tramline and for the area, in which the Yara N-sensor was used. A large-scale Fortschrit F 550 press was used to collect and compress straw. This press made it possible to compress straw into large-sized, $1.2 \mathrm{~m}$ x $0.8 \mathrm{n} \times 2.2 \mathrm{~m}$ cubes, weighing $250 \mathrm{~kg}$.

The energy parameters, i.e. the energy value of malting barley straw, were determined in a straw plant based in Zielonki, Sztumski district, using the Apator heat measuring device. To measure the water content in the straw, a Haymatic Digital meter was used, provided along with the heating equipment by the Danish company Voulund Danstoker. This probe measures moisture with $0.1 \%$ accuracy, through surface contact with the straw. The drying method was used to measure moisture content of the malting barley straw previously measured with a probe. Straw moisture measurements were made during the straw harvest, both in the field and in the heating plant, after placing it on the dosing surface. The heat produced was read in the heating plant at 6.00 and 18.00 , during the combustion of straw in a $500 \mathrm{KW}$ tin water boiler, at the current moisture of the straw. Heat measurements were made in MWh, using an Apator LQM heat meter.

\section{Results and discussion}

According to the established methodology, a unit grain mass of 4.26 tons of malting barley grain per ha was obtained from the zero tramline, and $5.38 \mathrm{t}$ per ha was obtained from the tramline supervised with the Yara N-Sensor processor. According to the measurement, the grain weight increased in the latter tramline by $1.12 \mathrm{t}$ per ha compared to the zero tramline.

Malting barley straw mass on the zero tramlines amounted to $1.24 \mathrm{t} \cdot \mathrm{ha}^{-1}$, and on trmlines supervised with the Yara N-Sensor processor, $2.16 \mathrm{t} \cdot \mathrm{ha}^{-1}$. This represents a malting barley straw biomass increase by $0.92 \mathrm{t} \cdot \mathrm{ha}^{-1}$. The obtained yields of grain and straw biomass allowed determining the ratio of grain to straw, which:

- for a zero tramline, with a straw yield of $1.24 \mathrm{t} \cdot \mathrm{ha}^{-1}$, the grain $(\mathrm{z})$ to straw (s) ratio was $\mathrm{z}: \mathrm{s}$ $=4,26 \mathrm{t}^{\circ} \cdot \mathrm{ha}^{-1}: 1,24 \mathrm{t} \cdot \mathrm{ha}^{-1}=1: 0.29$,

- for the tramline supervised with the Yara N-Sensor processor, the straw yield was $2.16 \mathrm{t} \cdot \mathrm{ha}^{-1}$, with a grain to straw ratio atz: $\mathrm{s}=5.38 \mathrm{t} \cdot \mathrm{ha}^{-1}: 2.16 \mathrm{t} \cdot \mathrm{ha}^{-1}=1: 0.40$. 
In the Zielonki heating plant, the following energy values for malting barley straw were obtained for a $500 \mathrm{KW}$ tin water boiler, and for operational (actual) straw humidity, i.e. 10\%, $12 \%, 16.5 \%, 21.2 \%$, and $24.6 \%$ water content: $13.1 \mathrm{GJ} \cdot \mathrm{t}^{-1}, 12.4 \mathrm{GJ} \cdot \mathrm{t}^{-1}, 10,0 \mathrm{GJ} \cdot \mathrm{t}^{-1}, 8.5 \mathrm{GJ} \cdot \mathrm{t}^{-1}$ and $7.4 \mathrm{GJ}^{-1}{ }^{-1}$, respectively. Figure 1 presents a graph of the malting barley straw's energy value dependency on the water content.

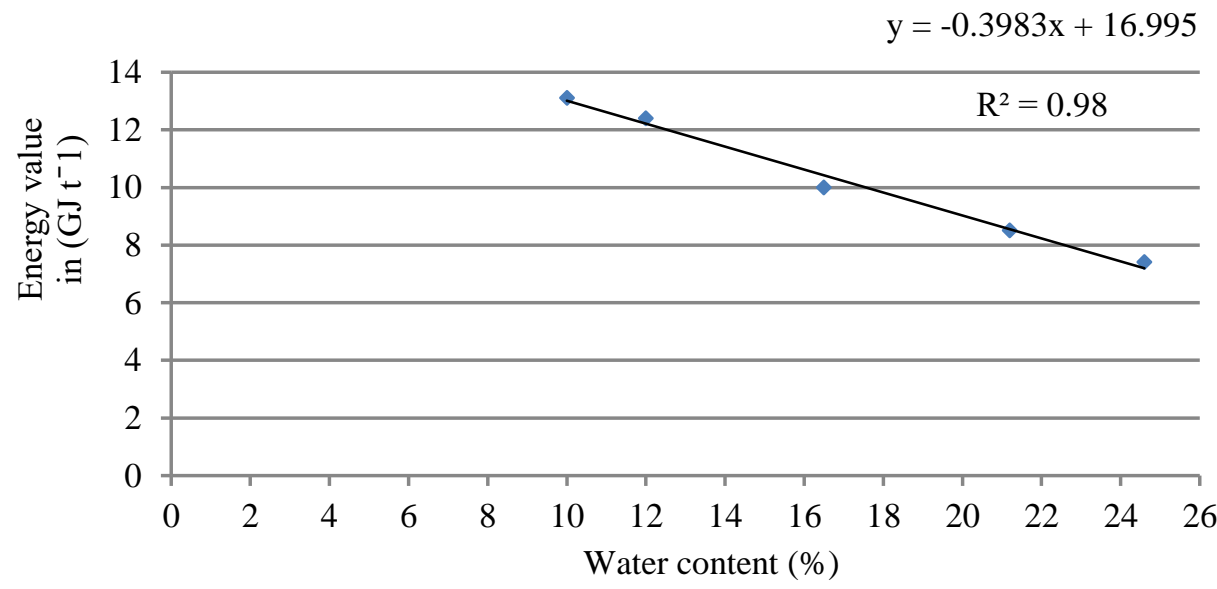

Figure 1. Graph of the malting barley straw's energy value dependency on the water content.

As observed in the applied barley straw boilers, the heat exchanger part in which straw combustion was taking place was clogging at above $800^{\circ} \mathrm{C}$. As a result of not cleaning the internal part of the boiler for six weeks, the ash of the burned straw formed a vitreous structure, which stuck to both the boiler's flame tube and its exchanger area. As a result, a decrease in heat production was observed. The resulting vitreous material acted as a thermal insulator that blocked the heat exchange between the burned straw and the boiler water jacket. This was confirmed by Danish studies (Nikolaisen, 1998 and Nilsson and Hansson, 2001). To document this phenomenon, appropriate photographs were taken, to demonstrate the consistency of ash formed after burning barley straw at a temperature above $800^{\circ} \mathrm{C}$ in the first, third and sixth week of combustion (Fig. 2). Kraszkiewicz et al. (2019) point to the problem of combustion quality, especially in the initial phase. Zając et al. (2017) and Konieczyński et al. (2017) also point to the type of pollution generated in the biomass combustion process which depend not only on process factors but also on the type of biomass burned. 
Elements of precision agriculture...

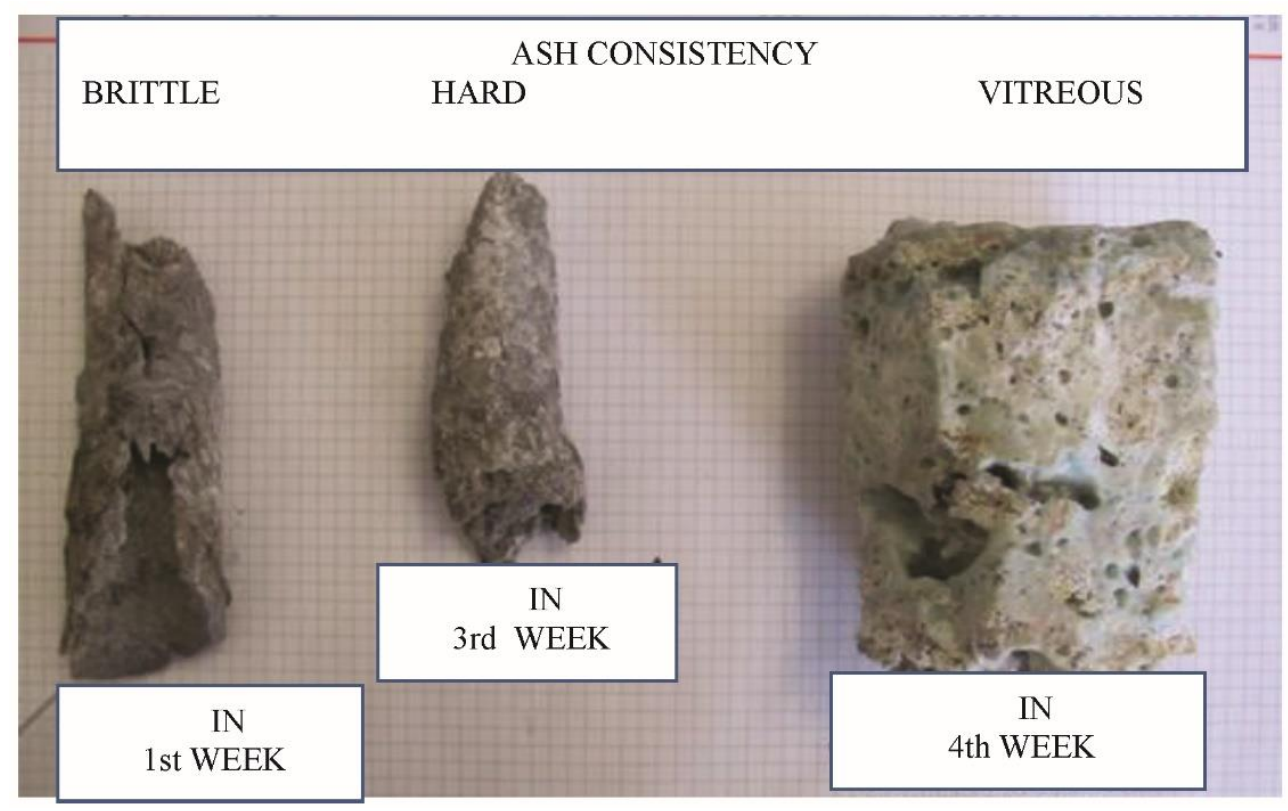

Figure 2. Sintered ash after burning barley straw, collected from the flame tube and exchanger area of the VOLUND Danstoker boiler in the first, third and sixth week of boiler operation.

\section{Conclusion}

Modern agricultural production, which follows the principle of sustainability, should be equipped with precise agricultural production tools, enabling optimization of management decisions of agrotechnical works. Using the Yara N-Sensor processor, precise application of mineral fertilizers according to determined fertilization demand allowed increasing the grain yield by $26 \%$ and the straw biomass yield by $74 \%$ compared to the control sample. The resulting increase in biomass obtained in the form of straw impacts its possible partial use for energy purposes without negative effects on the environment.

Expressing the energy value of malting barley straw as a function of its moisture allows a conclusion that between 10 and $25 \%$ water content, the energy value drops from 13.1 to $7.4 \mathrm{GJ} \cdot \mathrm{t}^{-1}$. At an average water content of $15 \%$, this gives a unit energy potential of 23.76 GJ $\cdot \mathrm{ha}^{-1}$.

As the observations of the combustion process have shown, barley straw cannot be used as a source of biomass for large-scale power production, since the ash melts at below $800^{\circ} \mathrm{C}$. 


\section{References}

Denisiuk, W. (2005). Rolnik żywnościowiec, czy producent energii i surowców energetycznych. Materiały Konferencyjne: Jubileuszowa Konferencja Naukowa pt. Problemy inżynierii rolniczej w aspekcie rolnictwa zrównoważonego, Uniwersutet Przyrodniczy w Lublinie, Lublin, 41-43.

Denisiuk, W. (2009). Optymalizacja zbioru stomy na cele grzewcze. Monografia pod redakcją naukową P. Gradziuka. VIII Konferencja MODR w Warszawie Odział w Płońsku, Płońsk, 79-84, ISBN 97883-60408-33-9.

Denisiuk, W. (2016). Mechanizmy działania pożytecznych mikroorganizmów w przywracaniu biologicznej równowagi w przyrodzie. Materiały Konferencyjne: Konferencja Naukowa nt. Bioremediacja zdegradowanych terenów przemysłowych, Wyższa Szkoła Techniczna w Katowicach, Katowice.

Denisiuk, W. , Piechocki, J. (2005). Technologiczne i ekologiczne aspekty wykorzystania słomy na cele grzewcze. Wydawnictwo UWM, ISBN 83-7299-410-2 Olsztyn.

Graham, S., Ogunfayo, I., Hall, M.R., Snape, C., Quick, W., Weatherstone, S., Eastwick, C. (2016) Changes in mechanical properties of wood pellets during artificial degradation in a laboratory environment. Fuel Processing Technology, 148, 395-402.

Grzybek, A. (2010). Modelowanie energetycznego wykorzystania biomasy. Wydawnictwo Instytutu Technologiczno-Przyrodniczego w Falentach, Falenty - Warszawa, ISBN 978-83-62416-08-0.

Guła, A. (2007). Zrównoważony rozwój energetyki. Seminarium nt. Niskonakładowe metody oszczędzania energii, Sztum.

Higa, T. (2003). Rewolucja $w$ ochronie naszej planety. Fundacja Źródła Życia. Warszawa, ISBN 83-7274-052-6.

Kraszkiewicz, A., Stryjecka, M., Nowosad, N., Kocira, S. (2018). Obciążenie środowiska produktami spalania peletów z biomasy roślinnej w kotle górnego spalania. Rocznik Ochrona Środowiska. 20 , 1269-1285.

Krzyżaniak, M., Stolarski, M.J., Szczukowski, S., Tworkowski, J. (2014). Thermophysical and chemical properties of biomass obtained from willow coppice cultivated in one- and three-year rotation cycles. Journal of Elementology. 1, 161-175.

Mytlewski A. i inni (2010) Logistyczne uwarunkowania produkcji energii cieplnej z wykorzystaniem surowców odnawialnych. ISBN Gdańsk

Nikolaisen, L.(1998). Straw for energy production. The Centre for Biomass Technology. Herning Dania

Nilsson, D., Hansson, P.-A. (2001). Influence of various machinery combination, fuel proportions and storage capacities on costs for co-handling of strow and red canary grass to district heating plants. Biomass Bioenergy. 4, 247-260.

Szyszlak-Bargłowicz, J., Piekarski, W., Krzaczek, P. (2006). Spalanie słomy jednym z kierunków jej wykorzystania. Energetyka. IX, 53-57.

Zając, G., Szyszlak-Barglowicz, J., Słowik, T., Wasilewski, J., Kuranc, A. (2017). Emission characteristics of biomass combustion in a do-mestic heating boiler fed with wood and Virginia Mallow pellets. Fresenius Environmental Bulletin. 26(7), 4663-4670.

Żmuda K. (2011). Priorytety MRiRW w zakresie energetycznego wykorzystania biomasy pochodzenia rolniczego - ważnego elementu WPR. Warszawa. 
Elements of precision agriculture...

\title{
WYKORZYSTANIE ELEMENTÓW ROLNICTWA PRECYZYJNEGO W UPRAWIE JECZMIENIA BROWARNEGO ORAZ WYKORZYSTANIE SLOMY JECCZMIENNEJ NA CELE ENERGETYCZNE
}

\begin{abstract}
Streszczenie. W pracy przedstawiono wyniki badań potencjału masy i energii słomy jęczmienia browarnego odmiany "Klas" wyznaczonego na plantacji 100 ha zlokalizowanej na Pojezierzu Iławsko Sztumskim. Precyzyjne aplikowanie nawozów mineralnych wg ustalonych potrzeb nawozowych przy pomocy procesora Yara N- Sensor, umożliwiło zwiększenie plonu ziarna o 26\% i biomasy słomy o 74\% w porównaniu do próby kontrolnej. Uzyskany wzrost pozyskiwanej biomasy w formie słomy wpływa na możliwość jej częściowego wykorzystania energetycznego bez negatywnych skutków dla środowiska. Przeprowadzone badania wartości energetycznej słomy jęczmienia browarnego w funkcji jej wilgotności pozwalają stwierdzić, że w przedziale od 10 do $25 \%$ zawartości wody, wartość energetyczna spada z 13,1 do $7,4 \mathrm{GJ} \cdot \mathrm{t}^{-1}$ co dla średniej zawartości wody $15 \%$ daje jednostkowy potencjał energii $23,76 \mathrm{GJ} \cdot \mathrm{ha}^{-1} \mathrm{Jak}$ wykazały obserwacje procesu spalania, słoma jęczmienna nie może być stosowana jako źródło biomasy dla sieciowej energetyki, ponieważ występuje zjawisko topienia się popiołu już w temperaturze poniżej $800^{\circ} \mathrm{C}$.
\end{abstract}

Słowa kluczowe: biomasa, kocioł wodny blaszany niskotemperaturowy, precyzyjne rolnictwo, słoma jęczmienna, wartość energetyczna 